\title{
IDENTIFIKASI GAYA BELAJAR MAHASISWA
}

\author{
Jeanete Ophilia Papilaya, Neleke Huliselan \\ FKIP, Universitas Pattimura \\ Kampus B - PGSD Unpatti Jl. Dr. Tamaela Ambon \\ anneth_op@yahoo.com
}

\begin{abstract}
The objective of this study was to identify learning styles of students. The approach used in this study is a quantitative approach with survey method. The variable in this study is a single variable, namely the identification of student learning styles. The study population is students of Guidance and Counseling FKIP Pattimura University totaling 388 people. Samples were used as samples in the amount of $10 \%$ of the population of 39 people. The sampling technique using Simple Random Sampling. Learning styles questionnaire prepared based on the opinion of De Poter \& Hernacki is used as a data collection tool. Learning styles identified as visual learning style, auditorial learning style, and kinesthetic learning style. Data analysis techniques in this study is the descriptive statistical analysis methods. Based on the survey results revealed that students of guidance and counseling FKIP Pattimura University has a tendency to one learning style. Of the 39 students found that 6 students had a tendency visual learning style, 20 students have a tendency to auditory learning style, 1 student has a tendency kinesthetic learning style, and 12 students have a tendency to mix between learning styles and learning styles visual auditory learning styles.
\end{abstract}

Keywords : visual learning styles; auditory learning styles; kinesthetic learning styles; students

\begin{abstract}
Abstrak
Penelitian ini mempunyai tujuan untuk mengidentifikasi gaya belajar mahasiswa. Pendekatan yang digunakan dalam penelitian ini adalah pendekatan kuantitatif dengan metode survey. Variabel dalam penelitian ini adalah variabel tunggal, yaitu identifikasi gaya belajar mahasiswa. Populasi penelitian adalah mahasiswa Program Studi Bimbingan dan Konseling FKIP Universitas Pattimura yang berjumlah 388 orang. Sampel yang digunakan sebagai sampel penelitian yaitu sebesar $10 \%$ dari populasi yang berjumlah 39 orang. Teknik pengambilan sampel dengan menggunakan Simple Random Sampling. Instrumen yang digunakan dalam penelitian ini adalah angket gaya belajar yang disusun berdasarkan pendapat teori gaya belajar menurut De Poter \& Hernacki. Gaya belajar yang diidentifikasi yaitu gaya belajar visual, gaya belajar auditorial, dan gaya belajar kinsetetik. Teknik analisis data dalam penelitian ini adalah dengan metode analisis statistik deskriptif. Berdasarkan hasil penelitian diketahui bahwa mahasiswa program studi bimbingan dan konseling FKIP Universitas Pattimura memiliki kecenderungan pada salah satu gaya belajar. Dari 39 mahasiswa diperoleh bahwa 6 mahasiswa memiliki kecenderungan gaya belajar visual, 20 mahasiswa memiliki kecenderungan gaya belajar auditorial, 1 mahasiswa memiliki kecenderungan gaya belajar kinestetik, dan 12 mahasiswa memiliki kecenderungan gaya belajar campuran antara gaya belajar visual dan gaya belajar auditorial.
\end{abstract}

Kata Kunci : gaya belajar visual; gaya belajar audiotorial; gaya belajar kinestetik; mahasiswa

\section{PENDAHULUAN}

Pendidikan adalah aspek yang sangat penting dalam menunjang kemajuan masa depan bangsa. Manusia sebagai subjek pembangunan perlu dididik, dibina, serta dikembangkan potensi-potensinya dengan tujuan terciptanya subjek-subjek pembangunan yang berkualitas. Salah satu sarana pendidikan yaitu universitas. Salah satu komponen yang berinteraksi untuk menunjang sistem pendidikan dalam universitas adalah mahasiswa. Fungsi dasar mahasiswa adalah bergelut dengan ilmu pengetahuan dan memberikan perubahan yang lebih baik dengan intelektualitas yang ia miliki selama menjalani pendidikan. 
Proses pembelajaran di universitas berbeda dengan di SMP/SMA. Mahasiswa dituntut untuk mampu belajar sendiri serta menganalisis permasalahan dalam pembelajaran. Pembelajaran yang efektif mampu mengakomodasi kebutuhan mahasiswa. Hal ini sesuai dengan pendapat Sugihartono (2007) yang mengatakan bahwa salah satu karakteristik pembelajaran yang efektif adalah jika pembelajaran dapat merespon kebutuhan siswa. Kebutuhan khusus berkaitan dengan keunikan atau perbedaan antar mahasiswa.

Menurut Siswoyo (2007) mahasiswa dapat didefinisikan sebagai individu yang sedang menuntut ilmu ditingkat perguruan tinggi, baik negeri maupun swasta atau lembaga lain yang setingkat dengan perguruan tinggi. Mahasiswa dinilai memiliki tingkat intelektualitas yang tinggi, kecerdasan dalam berpikir dan kerencanaan dalam bertindak. Berpikir kritis dan bertindak dengan cepat dan tepat merupakan sifat yang cenderung melekat pada diri setiap mahasiswa, yang merupakan prinsip saling melengkapi.

Setiap mahasiswa memiliki keunikan pribadi yang berbeda dengan mahasiswa yang lainnya. Setiap mahasiswa berbeda dalam tingkat kinerja, kecepatan belajar, dan gaya belajar. Perbedaan cara belajar ini menunjukkan cara termudah mahasiswa untuk menyerap informasi selama belajar. Cara termudah dan tercepat seseorang dalam belajar dikenal sebagai gaya belajar (Hamzah, 2010). Prashign (2007) mengatakan bahwa kunci menuju keberhasilan dalam belajar dan bekerja adalah mengetahui gaya belajar atau bekerja yang unik dari setiap orang, menerima kekuatan sekaligus kelemahan diri sendiri dan sebanyak mungkin menyesuaikan preferensi pribadi dalam setiap situasi pembelajaran, pengkajian maupun pekerjaan. Dengan demikian, gaya belajar merupakan kunci keberhasilan siswa dalam belajar.

Di dalam mengikuti proses pembelajaran, setiap mahasiswa memiliki gaya belajar yang berbeda-beda antara mahasiswa yang satu dengan yang lainnya. Dosen dalam mengajar harus memperhatikan gaya belajar mahasiswa. Ini dikarenakan dalam setiap mengajar efektifitasnya akan sangat bergantung pada cara atau gaya belajar mahasiswa, disamping sifat pribadi dan kemampuan intelektualnya.

Gaya belajar dari mahasiswa bisa diamati dari kecerdasan majemuk yang mereka miliki dan setiap mahasiswa memiliki kecerdasan masing-masing yang lebih dominan. Pentingnya dosen mengetahui gaya belajar seluruh mahasiswanya didasarkan pada kurang efektifnya pembelajaran di kelas. Musrofi (dalam Pratiwi, 2014) mengatakan hanya $30 \%$ mahasiswa yang berhasil mengikuti pembelajaran di kelas karena mereka mempunyai gaya belajar yang sesuai dengan gaya mengajar yang diterapkan dosen di dalam kelas. Sisanya, sebanyak $70 \%$ mahasiswa mengalami kesulitan dalam mengikuti pembelajaran di kelas karena mereka memiliki gaya belajar lain, yang tidak sesuai dengan gaya mengajar yang diterapkan di dalam kelas. Artinya, $70 \%$ gaya mahasiswa tidak terakomodasi oleh gaya mengajar dosen dalam pembelajaran.

Kekurangpahaman dosen terhadap gaya belajar mahasiswa berdampak merugikan mahasiswa. Hal ini akan mengakibatkan prestasi belajar mahasiswa tidak sesuai dengan taraf kemampuan inteligensi mahasiswa tersebut. Oleh sebab itu, dosen harus mengetahui dan mengenal gaya belajar setiap mahasiswa sehingga bisa mempermudah proses pembelajaran 
Penelitian yang dilakukan Buali, Balaha \& Muhaidab (2013) menghasilkan ada perbedaan yang signifikan gaya belajar antara siswa laki-laki dan siswa perempuan. Siswa laki-laki lebih cenderung gaya belajar konvergen, sedangkan siswa perempuan lebih cenderung gaya belajar divergen. Selain itu, Yazici (2005) dalam penelitiannya tentang bagaimana gaya belajar siswa dalam belajar dalam kinerja tim belajar menemukan bahwa gaya belajar dipengaruhi oleh pengalaman belajar, jenis kelamin, dan bidang studi yang diminatinya. Hasil penelitian lain yang dilakukan oleh Johnson \& Miller (2010) yaitu gaya belajar mahasiswa ditentukan oleh karakteristik bidang ilmu yang diambilnya. Mahasiswa yang belajar di disiplin ilmu fisika, matematika, dan kimia lebih cenderung untuk memiliki gaya belajar visual.

Sejalan dengan hasil penelitian yang dilakukan oleh Johnson \& Miller (2010) maka dalam penelitian ini memiliki karakteristik mahasiswa Program Studi Bimbingan dan Konseling FKIP Unpatti yang dilatih untuk lebih empati, peka terhadap lingkungan, serta memiliki kemauan untuk melayani orang lain yang bermasalah. Adanya karakteristik sifat mahasiswa Program Studi Bimbingan dan Konseling FKIP Unpatti ini maka peneliti ingin mengetahui bagaiaman gaya belajar para mahasiswa sehingga nantinya bisa memiliki karakteristik - karakteristik tersebut.

Gaya belajar merupakan cara yang dipilih seseorang untuk menggunakan kemampuannya (Santrock, 2010). Keefe (dalam Sugihartono, dkk, 2007) menyatakan bahwa gaya belajar berhubungan dengan cara anak belajar, serta cara belajar yang disukai. Sebagai cara yang disukai, maka mahasiswa akan sering menggunakan dan merasa mudah ketika belajar dengan gaya tersebut. Masing- masing mahasiswa akan merasakan gaya belajar mudah yang berbeda-beda. Setiap mahasiswa memiliki gaya belajar yang berbeda seperti yang dikatakan oleh Hamzah (2010) bahwa apa pun cara yang dipilih, perbedaan gaya belajar menunjukkan cara tercepat dan terbaik bagi setiap individu untuk bisa menyerap sebuah informasi dari luar dirinya.

Sukadi (2008) mengungkapkan bahwa gaya belajar yaitu kombinasi antara cara seseorang dalam menyerap pengetahuan dan cara mengatur serta mengolah informasi atau pengetahuan yang didapat. Sedangkan menurut Nasution (2008), gaya belajar adalah cara yang konsisten yang dilakukan oleh seorang murid dalam menangkap stimulus atau informasi, cara mengingat, berpikir, dan memecahkan soal.

Menurut De Poter \& Hernacki (1999), menjelaskan secara umum gaya belajar manusia dibedakan ke dalam tiga kelompok besar, yaitu gaya belajar visual, gaya belajar auditorial dan gaya belajar kinestetik. Gaya belajar visual adalah gaya belajar dengan cara melihat, mengamati, memandang, dan sejenisnya. Kekuatan gaya belajar ini terletak pada indera penglihatan. Bagi orang yang memiliki gaya ini, mata adalah alat yang paling peka untuk menangkap setiap gejala atau stimulus (rangsangan) belajar. Ciri-Ciri individu yang memiliki tipe gaya belajar visual yaitu menyukai kerapian dan ketrampilan, jika berbicara cenderung lebih cepat, suka membuat perencanaan yang matang untuk jangka panjang, sangat teliti sampai ke hal-hal yang detail sifatnya, mementingkan penampilan baik dalam berpakaian maupun presentasi, lebih mudah mengingat apa yang dilihat daripada yang didengar, mengingat sesuatu dengan penggambaran (asosiasi) visual, tidak mudah terganggu dengan keributan saat belajar, pembaca yang cepat dan tekun, lebih suka membaca sendiri dari pada dibacakan orang lain, tidak 
mudah yakin atau percaya terhadap setiap masalah sebelum secara mental merasa pasti, suka mencoret-coret tanpa arti selama berbicara di telepon atau dalam rapat, lebih suka melakukan pertunjukan (demonstrasi) daripada berpidato, lebih menyukai seni daripada musik, seringkali mengetahui apa yang harus dikatakan akan tetapi tidak pandai memilih kata-kata, serta kadangkadang suka kehilangan konsentrasi ketika mereka ingin memperhatikan.

Gaya belajar auditorial adalah gaya belajar dengan cara mendengar. Individu dengan gaya belajar ini, lebih dominan dalam menggunakan indera pendengaran untuk melakukan aktivitas belajar. Individu mudah belajar, mudah menangkap stimulus atau rangsangan apabila melalui alat indera pendengaran (telinga). Individu dengan gaya belajar auditorial memiliki kekuatan pada kemampuannya untuk mendengar. Ciri-Ciri individu yang memiliki tipe gaya belajar audiotorial yaitu saat bekerja sering berbicara pada diri sendiri, mudah terganggu oleh keributan atau hiruk pikuk disekitarnya, sering menggerakkan bibir dan mengucapkan tulisan dibuku ketika membaca, senang membaca dengan keras dan mendengarkan sesuatu, dapat mengulangi kembali dan menirukan nada, birama, dan warna suara dengan mudah, merasa kesulitan untuk menulis tetapi mudah dalam bercerita, pembicara yang fasih, lebih suka musik daripada seni yang lainnya, lebih mudah belajar dengan mendengarkan dan mengingat apa yang didiskusikan daripada yang dilihat, suka berbicara, berdiskusi, dan menjelaskan sesuatu dengan panjang lebar, dan lebih pandai mengeja dengan keras dari pada menuliskannya.

Gaya belajar kinestetik adalah gaya belajar dengan cara bergerak, bekerja, dan menyentuh. Maksudnya ialah belajar dengan mengutamakan indera perasa dan gerakan-gerakan fisik. Individu dengan gaya belajar ini lebih mudah menangkap pelajaran apabila bergerak, meraba, atau mengambil tindakan. Ciri-ciri individu yang memiliki tipe gaya belajar kinestetik yaitu berbicara dengan perlahan, menyentuh untuk mendapatkan perhatian, berdiri dekat ketika berbicara dengan orang, selalu berorientasi dengan fisik dan banyak bergerak, menghafal dengan cara berjalan dan melihat, menggunakan jari sebagai penunjuk ketika membaca, banyak menggunakan isyarat tubuh, tidak dapat duduk diam untuk waktu lama, memungkinkan tulisannya jelek, ingin melakukan segala sesuatu, dan menyukai permainan yang menyibukkan.

Penelitian ini mempunyai tujuan untuk mengidentifikasi gaya belajar mahasiswa Program Studi Bimbingan dan Konseling FKIP Universitas Pattimura (Unpatti).

\section{METODE}

Pendekatan yang digunakan dalam penelitian ini adalah pendekatan kuantitatif dengan metode survey. Variabel dalam penelitian ini adalah variabel tunggal, yaitu identifikasi gaya belajar mahasiswa. Definisi operasional gaya belajar yaitu cara individiu untuk menggunakan kemampuannya dalam berkonsentrasi, menyerap materi, menampung, serta memproses informasi yang baru dalam proses pembelajaran.

Populasi dalam penelitian ini yaitu keseluruhan mahasiswa Program Studi Bimbingan dan Konseling FKIP Unpatti yang berjumlah 388 orang. Sampel yang diambil sebagai sampel penelitian yaitu sebesar $10 \%$ dari populasi yang berjumlah 39 orang. Teknik pengambilan sampel dengan menggunakan simple random sampling.

Angket gaya belajar disusun berdasarkan De Poter \& Hernacki (1999) tentang tiga 
jenis gaya belajar, yang mencakup gaya belajar visual, gaya belajar auditorial, dan gaya belajar kinestetik. Jumlah pernyataan dalam angket gaya belajar secara keseluruhan yaitu sebanyak 36 aitem. Angket gaya belajar visual terdiri dari 11 aitem $(\alpha=0,84)$, angket gaya belajar auditorial terdiri dari 12 aitem $(\alpha=0,89)$, dan gaya belajar kinestetik terdiri dari 13 aitem $(\alpha=0,82)$. Semua pernyataan di dalam angket bersifat favorable dengan skor Sangat Setuju $(\mathrm{SS})=4$, Setuju $(\mathrm{S})=3$, Tidak Setuju $(\mathrm{TS})=2$, dan Sangat Tidak Setuju $($ STS $)=1$. Teknik analisis data dalam penelitian ini adalah dengan metode analisis statistik deskriptif.

\section{HASIL DAN PEMBAHASAN}

Penelitian ini melibatkan subjek sebanyak 39. Skor minimal yang diperoleh sebesar 1 dan skor maksimal sebesar 10. Rerata angket gaya belajar visual sebesar 4,62 dan standar deviasi sebesar 2,632. Untuk menentukan tinggi rendahnya hasil pengukuran setiap gaya belajar, digunakan 3 kategori yaitu tinggi, sedang, dan rendah.

Tabel 1

Hasil Analisis Deskriptif Gaya Belajar Visual

\begin{tabular}{cccccc}
\hline$M$ & SD & $\begin{array}{c}\text { Total } \\
\text { Item } \\
\text { Valid }\end{array}$ & N & $\begin{array}{c}\text { Nilai } \\
\text { Min }\end{array}$ & $\begin{array}{c}\text { Nilai } \\
\text { Maks }\end{array}$ \\
\hline 4,62 & 2,632 & 11 & 39 & 1 & 10 \\
\hline
\end{tabular}

Tabel 2

Kategori dan Frekuensi Gaya Belajar Visual

\begin{tabular}{cccc}
\hline Kategori & Skor & F & $\begin{array}{c}\text { Persentase } \\
(\%)\end{array}$ \\
\hline Tinggi & $\mathrm{X} \geq 7,3$ & 6 & $15,4 \%$ \\
\hline Sedang & $\begin{array}{c}3,7 \leq \mathrm{X}< \\
7,3\end{array}$ & 17 & $43,6 \%$ \\
\hline Rendah & $\mathrm{X}<3,7$ & 16 & $41 \%$ \\
\hline \multicolumn{2}{c}{ Total } & 39 & $100 \%$ \\
\hline
\end{tabular}

Tabel 3

Hasil Analisis Deskriptif Gaya Belajar

Auditorial

\begin{tabular}{cccccc}
\hline$M$ & SD & $\begin{array}{c}\text { Total } \\
\text { Item } \\
\text { Valid }\end{array}$ & N & $\begin{array}{c}\text { Nilai } \\
\text { Min }\end{array}$ & $\begin{array}{c}\text { Nilai } \\
\text { Maks }\end{array}$ \\
\hline 7,77 & 2,748 & 12 & 39 & 3 & 12 \\
\hline
\end{tabular}

Dari tabel 2 dapat dilihat bahwa hampir sebagian besar mahasiswa memiliki gaya belajar visual pada kategori sedang (43,6\%). Adapun Mean angket gaya belajar audiotorial sebesar 7,77 dan Standar Deviasi sebesar 2,748 dengan jumlah subyek (N) 39. Diperoleh skor minimal sebesar 1 dan skor maksimal sebesar 10 . Adapun pembagian 3 kategori pada gaya belajar auditorial dapat dilihat pada tabel 4 .

Tabel 4

Kategori dan Frekuensi Gaya Belajar Auditorial

\begin{tabular}{cccc}
\hline Kategori & Skor & F & $\begin{array}{c}\text { Persentase } \\
(\%)\end{array}$ \\
\hline Tinggi & $X \geq 8$ & 20 & $51.3 \%$ \\
\hline Sedang & $4 \leq \mathrm{X}<8$ & 16 & $41 \%$ \\
\hline Rendah & $X<4$ & 3 & $7.7 \%$ \\
\hline \multicolumn{2}{c}{ Total } & 39 & $100 \%$ \\
\hline
\end{tabular}

Dari tabel 4 dapat dilihat bahwa hampir sebagian besar mahasiswa memiliki gaya belajar auditorial pada kategori tinggi $(51.3 \%)$. Mean angket gaya belajar kinestetik sebesar 2,46 dan Standar Deviasi sebesar 2,644 dengan jumlah subyek (N) 39. Diperoleh skor minimal sebesar 1 dan skor maksimal sebesar 13.

Tabel 5

Hasil Analisis Deskriptif Gaya Belajar Kinestetik

\begin{tabular}{cccccc}
\hline$M$ & SD & $\begin{array}{c}\text { Total } \\
\text { Item } \\
\text { Valid }\end{array}$ & $\mathrm{N}$ & $\begin{array}{c}\text { Nilai } \\
\text { Min }\end{array}$ & $\begin{array}{c}\text { Nilai } \\
\text { Maks }\end{array}$ \\
\hline 2,46 & 2,644 & 13 & 39 & 0 & 13 \\
\hline
\end{tabular}

Pembagian 3 kategori pada gaya belajar kinestetik dapat dilihat pada tabel 6 dibawah ini.

Tabel 6 
Kategori dan Frekuensi Gaya Belajar Kinestetik

\begin{tabular}{cccc}
\hline Kategori & Skor & F & $\begin{array}{c}\text { Persentase } \\
(\%)\end{array}$ \\
\hline Tinggi & $X \geq 8,7$ & 1 & $2,6 \%$ \\
\hline Sedang & $\begin{array}{c}4,3 \leq X< \\
8,7\end{array}$ & 6 & $15,4 \%$ \\
\hline Rendah & $X<4,3$ & 32 & $82 \%$ \\
\hline \multicolumn{2}{c}{ Total } & 39 & $100 \%$ \\
\hline
\end{tabular}

Dari tabel 6 dapat dilihat bahwa hampir sebagian besar mahasiswa (82\%) memiliki gaya belajar kinestetik pada kategori rendah.

Berdasarkan hasil analisis dari angket gaya belajar visual, angket gaya belajar auditorial, dan angket gaya belajar kinestetik, maka diketahui kecenderungan gaya belajar mahasiswa jika dilihat dari skor kategori tinggi. Adapun hasilnya menunjukkan bahwa 6 mahasiswa memiliki kecenderungan gaya belajar visual, 20 mahasiswa memiliki kecenderungan gaya belajar auditorial, 1 mahasiswa memiliki kecenderungan gaya belajar kinestetik, dan 12 mahasiswa memiliki kecenderungan gaya belajar campuran antara gaya belajar visual dan gaya belajar auditorial.

Jika digambarkan dengan grafik maka frekuensi mahasiswa yang memiliki kecenderungan gaya belajar visual, auditorial, kinestetik, maupun campuran tampak pada gambar 1 .

Berdasarkan hasil penelitian diketahui bahwa mahasiswa program studi bimbingan dan konseling FKIP Unpatti memiliki kecenderungan pada salah satu gaya belajar. Dari 39 mahasiswa diperoleh bahwa 6 mahasiswa memiliki kecenderungan gaya belajar visual, 20 mahasiswa memiliki kecenderungan gaya belajar auditorial, 1 mahasiswa memiliki kecenderungan gaya belajar kinestetik, dan 12 mahasiswa memiliki kecenderungan gaya belajar campuran antara gaya belajar visual dan gaya belajar auditorial.

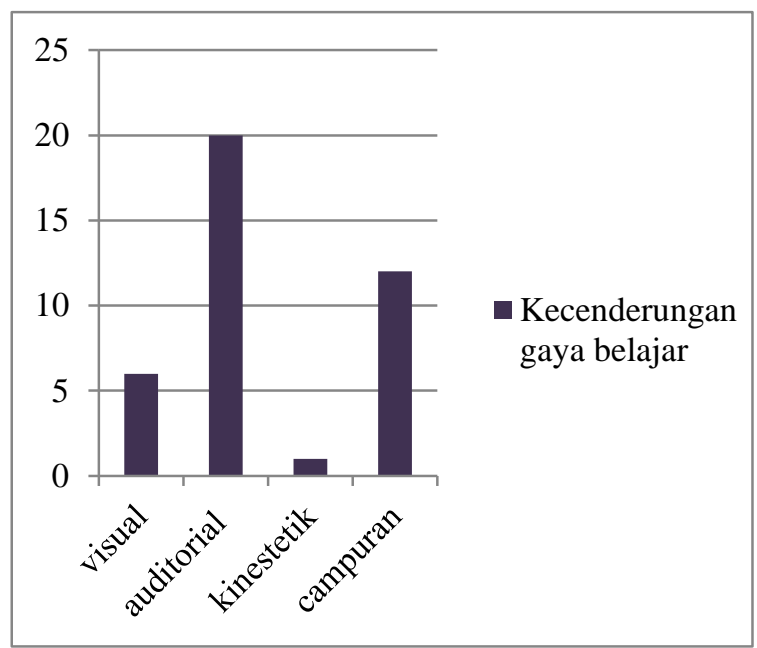

Gambar 1. Frekuensi Kecenderungan Gaya Belajar Mahasiswa

Hasil penelitian ini berbeda dengan penelitian yang dilakukan oleh Buali, Balaha \& Muhaidab (2013) dimana jenis kelamin tidak menentukan gaya belajar seseorang. Begitu juga hasil penelitian ini tidak sejalan dengan penelitian yang dilakukan oleh Yazici (2005) dan Johnson \& Miller (2010) dimana gaya belajar seseorang pun tidak ditentukan oleh pengalaman belajar dan bidang studi yang dipelajarinya.

Hasil penelitian menunjukkan bahwa mahasiswa program studi bimbingan konseling FKIP Unpatti yang memiliki kecenderungan gaya belajar visual lebih suka membaca. Hal ini sesuai dengan pendapat De Poter \& Hernacki (1999) bahwa gaya belajar visual lebih suka membaca. Mahasiswa dengan gaya belajar visual akan cenderung untuk lebih mudah mengingat sesuatu berdasarkan penglihatannya, lebih memahami suatu perintah jika membaca perintah tersebut, bahkan bisa menikmati bacaan meskipun sedang berada di tengah keributan. 
Mahasiswa program studi bimbingan dan konseling FKIP Unpatti yang memiliki kecenderungan gaya belajar auditorial lebih mudah terganggu oleh keributan. Hal ini sesuai dengan pendapat De Poter \& Hernacki (1999) bahwa gaya belajar auditorial lebih dominan dalam menggunakan indera pendengaran untuk melakukan aktivitas belajar. Oleh sebab itu, mahasiswa program studi bimbingan dan konseling FKIP Unpatti yang memiliki kecenderungan gaya belajar auditorial akan mengalami kesulitan ketika membaca materi ketika teman-temannya ramai di dalam kelas, tidak bisa konsentrasi jika ada keributan, bahkan tidak bisa focus belajar jika ada music yang diputar dengan volume besar. Hal ini disebabkan karena mahasiswa dengan gaya belajar auditorial lebih cenderung untuk menggunakan telinganya sebagai media belajar, sehingga apabila ada suara-suara lain yang berasal dari luar fokus belajarnya maka ia tidak akan bisa konsentrasi dalam belajar.

Gaya belajar kinestetik yang dimiliki oleh mahasiswa program studi bimbingan dan konseling FKIP Unpatti sangat lemah dalam aktivitas verbal. Hal ini sesuai dengan pendapat dari De Poter \& Hernacki (1999) yang mengatakan bahwa orang dengan gaya belajar ini lebih mudah menangkap pelajaran apabila ia bergerak, meraba, atau mengambil tindakan. Hal inilah yang membuat mahasiswa program studi bimbingan dan konseling FKIP Unpatti yang memiliki kecenderungan gaya belajar kinestetik tidak bisa mengingat materi dengan cara menghapal, lebih senang bersentuhan secara fisik ketika berbicara dengan orang lain, bahkan berbicara sangat pelan ketika sedang melakukan presentasi di kelas.

Fasilitas yang disediakan oleh Program Studi Bimbingan dan Konseling FKIP Unpatti sudah memadai dalam proses pembelajaran. Fasilitas yang ada yaitu perpustakaan, audio system, infocus, laptop, televisi, kamera, dan ruangan kuliah. Semua fasilitas tersebut dapat menunjang proses pembelajaran mahasiswa dengan ketiga gaya belajar.

Bagi mahasiswa yang memiliki kecenderungan gaya belajar visual diharapkan untuk lebih giat membaca dalam proses belajar mengajar, khususnya ketika sedang kuliah. Bagi mahasiswa yang memiliki kecenderungan gaya belajar auditorial diharapkan untuk bisa merancang suatu proses belajar yang menggunakan suara sehingga lebih mudah untuk memahami sebuat materi belajar, seperti psychomovie dan psychoclip. Sedangkan bagi mahasiswa yang memiliki kecederungan gaya belajar kinestetik untuk selalu menggunakan peraga dalam belajar, seperti praktikum dalam perkuliahan.

Bagi para dosen agar lebih peka dan memahami gaya belajar masing-masing mahasiswa sehingga dapat membantu mereka dalam proses belajar. Selain itu, diharapkan juga untuk dosen memadu padankan metode pembelajaran dimana ada ketiga model gaya belajar ini sehingga para mahasiswa lebih mudah untuk memahami dan mengerti materi yang diberikan. Hal ini juga akan berdampak pada peningkatan prestasi belajar mahasiswa (IPK).

\section{KESIMPULAN}

Berdasarkan hasil penelitian yang telah dilakukan maka dapat diambil kesimpulan bahwa setiap mahasiswa program studi bimbingan dan konseling FKIP Unpatti memiliki kecenderungan pada salah satu gaya belajar baik gaya belajar visual, gaya belajar auditorial, dan gaya belajar kinestetik. Sebagian besar mahasiswa memiliki kecenderungan gaya belajar auditorial sebanyak 20 mahasiswa. Selain itu juga sebanyak 6 mahasiswa memiliki kecenderungan gaya belajar visual, 1 
mahasiswa memiliki kecenderungan gaya belajar kinestetik, dan 12 mahasiswa memiliki kecenderungan gaya belajar campuran antara gaya belajar visual dan gaya belajar auditorial.

\section{DAFTAR PUSTAKA}

Buali, H. W., Balaha, H. M., Muhaidab, S. N. A. (2013). Assessment of learning style in a sample of saudi medical students. Journal of Acta Inform Medical, 21(2). 83-88.

De Poter, B. \& Hernacki, M. (1999). Quantum learning. Yogyakarta: Kaifa.

Hamzah, B. U. (2010). Orientasi baru dalam psikologi siswa yang memiliki gaya belajar. Jakarta: Bumi Aksara

Johnson, A., \& Miller, J. (2010). Comparison of student's learning style in STEM discipline. Proceedings of the Industrial Engineering Research Conference.

Nasution, S. (2008). Berbagai pendekatan dalam proses belajar mengajar. Bandung: Bumi Aksara

Prashign, B. (2007). The power of learning styles: Memicu anak melejitkan prestasi dengan mengenali gaya belajarnya. Bandung: Kaifa.

Pratiwi, D. (2014). Gaya belajar dominan pada siswa berprestasi dalam kegiatan siswa yang memiliki gaya belajar di SD Negeri 2 Gombong tahun ajaran 2013/2014. Jurnal FKIP, 7(3). Diakses dari http://jurnal.fkip.uns.ac.id/index.ph p/pgsdkebumen/article/view/4016.

Santrock, J. W. (2010). Psikologi pendidikan: Edisi kedua. Jakarta: Kencana.

Siswoyo, D. (2007). Ilmu pendidikan. Yogyakarta: UNY Pers.

Sugihartono., Fathiyah, K. N., Harahap, F., Setiawati, F. A., \& Nurhayati, S. R. (2007). Psikologi pendidikan. Yogyakarta: UNY Press.

Sukadi. (2008). Progressive learning: Learning by spirit. Bandung: MQS.

Yazici, H. J. (2005). A study of collaborative learning style and team learning performance. Education \& Training Journal, 47, 216-229. 